\title{
Challenges of Language Policy in Youth Media: Minority media and language policymakers converging in goals
}

\author{
Hizkuntza-politikaren erronkak gazteen \\ komunikabideetan: hizkuntza-politiken \\ eta medio-politiken helburuak harmonizatzen
}
Desafíos de la política lingüística en los medios de comunicación para jóvenes: armonizando los objetivos de las políticas lingüísticas y las políticas mediáticas

\section{Agurtzane Elordui ${ }^{1}$}

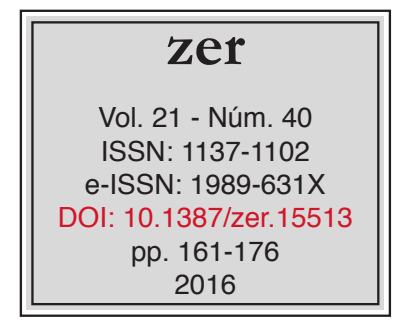

Recibido el 18 de mayo de 2015, aceptado el 3 de mayo de 2016.

\begin{abstract}
In the current digital media environments, the effectiveness of the policies of media in minority languages will depend on their ability to attract young users to interact with media. Participation seems particularly relevant for an interaction strategy to attract young people, a relevant issue that links the goals of any plan for language revival with a strategy for new media development. This work analyzes the patterns of participation of two public minority media, namely BBC ALBA's and EITB's strategies. It has focused on successful participative proposals, such as the cases of FilmG and Gaztea, where there are interesting guidelines to increase the visibility of minority content in a global market.
\end{abstract}

Keywords: Language policy, minority media, participation, young media, BBC ALBA, EITB.

UPV/EHU, agurtzane.elordui@ehu.eus 


\section{Laburpena}

Egungo medio digitalen testuinguruan hizkuntza gutxitua darabilten komunikabideen arrakasta medio horiek gazteen parte-hartzea sustatzeko duten gaitasunaren araberakoa izango da. Parte-hartzeak, gainera, estuki lotzen ditu egungo komunikabideen helburu estrategikoak eta hizkuntza-normalizazio plangintzarenak. Helburu biak ikusmiran, ikerketa honetan BBC ALBA eta EITB komunikabide publikoek gazteei zuzentzen dizkien partehartze estrategiak ikertu dira. Bereziki FilmG eta Gaztea proposamen arrakastatsuetan jarri da arreta, Interneterako sortzen diren edukietan gazteek parte har dezaten sustatzeko darabiltzaten estrategietan. Proiektu horietan aurkitu dira merkatu globalean ikusgarritasuna lortzeko edozein komunikabide minoritariok gogoan izateko jarraibide interesgarriak.

Gako-hitzak: Hizkuntza politika, komunikabide minoritarioak, parte-harteza, komunikabide berriak, BBC ALBA, EITB.

\section{Resumen}

En el entorno digital la eficacia de las políticas de los medios minoritarios depende de su capacidad para atraer a usuarios jóvenes y hacerles participar. La participación es una cuestión relevante que vincula los objetivos de cualquier plan de normalización lingüística con una estrategia para el desarrollo de nuevos medios. Este trabajo analiza los patrones de participación de dos medios minoritarios públicos: BBC ALBA y EITB. Se centra en propuestas participativas exitosas como FilmG y Gaztea, que muestran pautas a seguir para el diseño de estrategias que ayuden a aumentar la visibilidad de los contenidos en lengua minoritaria en un mercado global.

Palabras clave: Política lingüística, medios minoritarios, participación, nuevos medios, BBC ALBA, EITB. 


\section{Introduction}

Media and communication technologies are simultaneously diverging and converging, resulting in a complex, fast changing and increasingly global media environment that poses many challenges for language policy. In this new media model, minority media policymakers have to face an extra challenge: They must attract young people to active use in the minority language in question. That challenge seems to be more and more difficult in a communicational context in which young people's engagements with the new media are increasingly translocal and heteroglossic (Leppänen et al., 2009).

The new approach to consumption on the Internet on the part of those young generations has led in the recent years to a reflection on the need for a new approach to the public service of media (Bardoel, 2007; Bardoel \& d'Haenes, 2008; Jakubowick, 2008). In the field of Public Media Policy, an audience participation strategy is proposed as a media strategy to attract new and more loyal young audiences, and also as a stimulus for developing innovative media formats (Bardoel, 2007; Jakubowick, 2006, 2008; Ofcom, 2007). This paradigm has been considered by many as a vital requirement to be successful in the networked communicational context (Jakubowick, 2006a, 2008; Jenkins 2006, Jenkins et. al., 2013; Ofcom, 2007).

Minority media should take that strategy into account: because of its vital role in the potential success of the media in question, but also because of its potential for community building; indeed, both these ideas seem to be largely linked in the current media landscape. In this work I will analyse the policy measures of two minority media, namely BBC Scotland's ALBA ${ }^{2}$ and the Basque EITB $^{3}$ to attract young people to media in Scottish Gaelic and Basque. That analysis reveals the need to attune the goals of both media policy and language policy in minority media, and also the need for a radical change in the way we understand language policy itself: the involvement of young people in new media consists mostly of 'bottom-up' activity, with initiatives being developed by the users themselves. They are not 'policeable in the way that the old media were' (Cormack, 2013: 258).

In this work, I will first outline the challenge of language policy in the new media market by specifically addressing the new forms of communication among and community of young people. Second, I will examine the role of these minority public media in attracting young people to the media and how they are able to accommodate their main public remits. Thirdly, I will analyse the policy measures of BBC ALBA and EITB to attract young people to Internet content, by taking into account the patterns of interaction they promote among young people, and also how successful those measures have been according to statistic data.

\footnotetext{
2 BBC ALBA is a partnership service between MG ALBA and the BBC to deliver Gaelic television, radio and online services: The partnership came into effect officially in 2008 and delivers a trimedia Gaelic digital service comprising the television channel BBC ALBA, the established Gaelic radio station BBC Radio nan Gaidheal, and online services including www.bbcalba.co.uk and "watch again" facilities on the BBC IPlayer.

3 Euskal Irrati Telebista (EITB, Basque Radio-television) is the Basque Country's public broadcast service. The EITB group is the leading media group in the Basque Country with five television channels (ETB1, ETB2, ETB3, ETB Sat and Canal Vasco), five radio stations (Euskadi Irratia, Radio Euskadi, Radio Vitoria, Gaztea and EITB irratia) and, on the Internet, eitb.eus, gaztea.eus, and hiru3.eus.
} 


\section{Challenges of Language Policy in the New Media}

In the new communicational context, language policy applied to media, or media language policy, is challenged from both a macro and from a micro perspective. From a macro perspective, in supranational regulatory bodies, the question of the management of linguistic diversity and minority languages on the Internet is still an unresolved matter. The efficacy of language policy action plans, such as the European Charter for Regional and Minority Languages (1992) (ECRML) and the Framework Convention for the Protection of National Minorities (1995), has been called into question. More than one observer has emphasised the need to fulfil such international legal requirements through approaches that are better suited to the new information age (McGonagle, 2011; Moring, 2006, 2013; Moring \& Dunbar, 2008). Moring (2013), for example, calls for urgent measures to compensate for the asymmetric position of minority languages in the new media markets:

The third wave that the world is now witnessing involves service providers, with a background in traditional media, moving great resources into content production for new platforms in an effort to survive. This will further change the market, if no restitutive policies are put in place, it will do so to the benefit of the sizeable audiences that speak the big language of the world (Moring, 2013: 47).

From a micro point of view, the biggest challenges come from the fusion of mass media communication and interpersonal communication on the Internet. As Browne and Uribe-Jongbloed (2013: 26) highlight, media have become domains of daily life. The data are relevant if we analyse Internet use among children and young people: according to the Ofcom report on children's media use and attitudes in 2013 (Ofcom, $2014 \mathrm{a}$ ), $80 \%$ of children between 5 and 15 use the Internet every week. Children in Scotland spent more than 20 hours every week using the Internet and video games, that is, around 3 hours every day. In the whole UK, meanwhile, 16-24s spend 261 minutes per day on communication activities in 2014 (Ofcom, 2014b: 5).

The data are quite similar in the case of the Basque Country. According to recent research carried out by the Basque Government on media use by young Basques, published in 2012 (Basque Government, 2012a), almost 100\% of young Basque people between 15 and 29 had used the Internet in the previous year. $81 \%$ use the Internet every day and $43 \%$ of people in that age-group spent 2 or more hours every day on the net.

In Europe, the media have evolved from being a merely incidental element of private life and leisure into becoming completely embedded in families' everyday lives (Livingstone and Das, 2010 and 2013). The results of the Basque Government research reveal much the same findings: relationships in the domains of both the family and friendship networks are being increasingly developed through the media: when asked about their use of social networks, $80 \%$ of young Basque people state that they use those services mostly to communicate with their family and with 
friends in everyday situations (Basque Government, 2012a: 50). The new media practice of young Basques thus shows that the media is a major force shaping their everyday lives. The media have an important social function at the local level of the young peoples' personal lives in enhancing their contacts and interactions with their friends and family. For all that, media communication and everyday communication can no longer be seen as separate spheres of use in language policy. One of the biggest challenges of minority media policy is to interact with young people in their everyday activities, which in the Basque and Scottish cases are mostly in Spanish (Basque Government, 2013) and English (Stùbhart, 2008) respectively.

Yet these new challenges for media language policy do not just stem from the sphere of use, but also from the new patters of consumption by young people. Internet users are more and more active creators and contributors of content, and those new participative consumption patterns are particularly prevalent amongst younger audiences (Livingstone, 2009; Livingstone \& Das, 2013). In this new media model, minority media policymakers have to attract young people to active use in the minority language. That seems particularly difficult in the current media context: Young people's engagement with the new media is no longer organised solely on the basis of local or national identifications but is increasingly translocal (Leppänen et al., 2009). More often than not young people are motivated by the particular aesthetic, social and cultural norms and conventions of the new media environments in which more global languages such as English and Spanish are prevalent. As Leppänen et al. (2009) show for the Finnish case, translocality especially manifests itself in language choice and in linguistic and stylistic heteroglossia ${ }^{4}$.

Because of that complex communicational environment, language policy proposals such as Functional completeness by Moring (2007) are difficult to implement. Moring defines Functional completeness as 'That means that speakers of the language, if they so choose, can live their life in and through the language without having to resort to other languages, at least within the confines of everyday matters in their community' and emphasises that a necessary but not sufficient condition for this is the Institutional Completeness of different service providers in a language, that is, that there should be media platforms available in the minority language for each type of media.

To achieve that latter goal in the Internet world seems almost impossible for most of the many minority languages. As Pietikäinen and Kelly-Holmes (2011: 60) emphasise when talking about Moring's proposal, and including it in what they call the 'service era' of minority media policy, '...there is a realization that media alone are not a panacea, and that top-down management may not be the way forward'. Nowadays, in what Pietikäinen and Kelly-Holmes call the 'performance era', institutional and functional completeness is not the main goal. In this new context, '...the state and community are still key actors in minority-language media both at national and community levels, but they are supplemented, and in some cases supplanted, by a multiplicity of other actors' (Pietikäinen \& Kelly-Holmes, 2011: 61). Particularly

\footnotetext{
${ }^{4}$ Heteroglossia is here defined as a of range linguistic and discursive resources available for self-expression, communication, and identification. It makes possible to identify not only the co-occurrence of and shifts between languages or language varieties, but also how language uses index ideological points of view and engage with larger social, historical, and ideological processes (Leppänen et al., 2009).
} 
in the case of media for young people, the mere existence of media services does not ensure that young people will choose them for media communication. Young people are nowadays some of the most significant policing actors that I mentioned before.

\section{Public minority media and language policymakers: converging in goals}

In the European context, Jakubowick (2006a, 2007, 2008), at that time chair of the Council of Europe's Steering Committee on the Mass Media, demanded a Copernican revolution in the way we understand the public media ${ }^{5}$ and proposed internal and external changes in the public media based on the promotion of participation and the partnership of civil society (Jakubowick, 2008: 2).

The main guidelines of this media view constitute a cross-media strategy whereby programme production is not separated by media channel, but by programme genre. That strategy enables synergies of resources and the cross-fertilization of ideas in the media. Its main challenge is the need for multi-skilling among journalists and production staff enabling them to produce material for more than one medium.

However the cornerstone of this strategic media proposal is the promoting of audience participation in public media. Audience participation is seen as a tool for people's empowerment, as a way for ordinary people to take part in the public debate. Including in this strategy small groups with specific needs such as minority language groups and providing them content and services to do so are, in this view, considered to be public media obligations (Jakubowick, 2007: 18).

But audience participation is also a media strategy whereby media institutions implement feedback opportunities to attract more loyal audiences. In this sense, it represents a new source of revenue for broadcasters and can be seen as one of the major drivers in the development of new and innovative media formats. Jakubowick recognizes that there is a main avenue still to explore in how to introduce users' content without compromising the quality of public media but, at the same time, he sees it as a vital requirement to be successful in the networked communicational context.

In the case of minority media, more than one contends (UNESCO 2011a, $2011 \mathrm{~b})$ that this new view of public media has to be taken into account because of that 'vital' character, but also because of the new opportunities it provides for the other public remit that justifies the existence of these media, that is, for the maintenance and promotion of the minority language. As Jakubowick (2006b) emphasises, the Web 2.0 phenomenon should be given special attention in the context of new minority media, because of the many new opportunities it provides for self-expression and communication for individuals and groups within minority communities. Cormack (2013: 259) points out that the openness for dialogue between the media and the user suggests that media can become an important tool in community building, and also generators of greater development of new language usage spheres for the minority language in question. It may be a media strategy

\footnotetext{
5 Similar proposals can also be found in the British (Ofcom, 2007) and American context, in this latter case also known as Public Media 2.0 (Clark \& Aufderheide, 2009).
} 
that turns out to be fruitful for both: for the development of those media on the Internet and, at the same time, for the development of new language usage spheres for minority languages.

Participation seems particularly relevant for an interaction strategy to attract young people, a relevant issue that links the FOR WHOM of any plan for language revival with a strategy for new media development. According to Bardoel (2007: 45), the interaction strategies needed to improve the relationship between the broadcasters and its young public are mostly of a participative nature. This strategies are: a) to give to the young the possibility of engaging with the media by sharing, commenting, promoting or criticizing content; b) to give the option of creating their own material or getting involved in the design, production or distribution of content for media and c) to give full priority to on-demand services.

In fact, young people are the main target in that strategy of participative public media. By taking into account research into the satisfaction levels of teenagers and young adults (data from Scotland provided by Ofcom) which reveal that the youth of the UK are dissatisfied with the current delivery of public service programming $^{6}$, Jakubowick emphasizes that the behaviour of young people is of particular interest in any strategy within media. The reason for this is not just to understand their interaction with the market at present, but also as an indicator for future media developments.

In line with this participatory policy based on user-generated content are the proposals to include Media and Information Literacy (MIL) within the public media (Livingstone \& Wang, 2011). According to Scott (2009: 14), MIL activities are often the results of collaborations of broadcasters with schools, colleges and universities. Scott highlights the case in Canada of MediaSmarts (formally known as The Media Awareness Network), which has been developing digital and media literacy programmes and resources for Canadian schools and communities since 1996. Through its work it supports adults with the necessary information and tools so they can help children and teens to develop the critical thinking skills they need for interacting with the media.

As Scott contends (2009: 31), that partnership collaboration between broadcasters and colleges or universities can be beneficial for both parties: Universities provide venues, logistical expertise and access to students and communities that broadcasters do not have. Moreover, they benefit from the fact that, as a result of such practices, students are likely to produce content of higher quality. In fact, broadcasters can play a key role in helping to ensure that students get these skills, which only can be acquired through practical experience in the media. Major public media such as the $\mathrm{BBC}$ see advantages in this strategy and they include media literacy planning in their media policy. They emphasise, among other things, the need to encourage audiences to experiment creatively with digital media in order to contribute to the BBC's output and participate in wider society and engage within and across communities of interest (BBC, 2013: 3).

\footnotetext{
${ }^{6}$ Similar conclusions can be drawn from the Basque Government's Youth Observatory study. When Basque young people are asked for their preferences in terms of TV channels, the public media are not their first choices. They chose LaSexta (\%19), Antena 3(\%18), Cuatro (\%16) and Tele5 (\%15) much before TV1 (6\%), EITB1 (5\%) and EITB2 (5\%).
} 


\section{BBC ALBA and EITB: media strategies to improve youth participation in Scottish Gaelic and Basque}

In the last National Gaelic Language Plan for 2012-17 the media is considered 'vital' to the future of Gaelic: 'for maintaining loyalty to the language, in supporting language acquisition and also in providing a unique cultural heritage and personal expression in Gaelic' (Bord na Gaidhling, 2012: 38). According to the Bòrd na Gàidhlig $^{7}, \mathrm{BBC}$ ALBA has a vital role to play in relation to providing opportunities to learn and use Gaelic ${ }^{8}$, to enabling its use in a range of employment sectors, to increasing its visibility, to supporting its status and to providing an impetus for continuing corpus development. The Bòrd considers BBC ALBA to be a key partner in delivering an ambitious plan to create a new generation of Gaelic speakers and a crucial element in the revitalisation and normalisation of Gaelic. In fact, in its view, the creation of a new generation of Gaelic speakers is dependent on attracting and retaining young people and the Bòrd believes that BBC ALBA has a crucial role in ensuring this happens (Bòrd na Gàidhlig, 2012: 36) ${ }^{9}$.

Also in the reflections and reviews of the Basque Plan promoted by the Basque Government from 2005 to 2009 in the open reflection called Euskara 21 and particularly in Hedabideak Media Initiative, show a significant change in the perception of the media as a stimulus for language revitalisation. Specifically, in the 2012 Action Plan for the Promotion of the Basque Language (Basque Government, 2012b), the media are categorised as "high priority" and the plan explains specific steps that have to be taken to promote Basque-language content on the Internet and facilitate ways to promote the presence of Basque on social networks (Basque Government, 2012b: 94).

The main issue now seems to be focused on implementing those new policy guidelines in the public minority media. In the 2012 plan for the promotion of Basque, there is a clear reference to the public media in that respect. The plan highlights the need to open up a reflection on the obligations of the public media in the revival of Basque; a reflection that, according to the plan (Basque Government, 2012b: 78), should be carried out between the Basque Government's Department of Language policy and the Basque public media of EITB.

From 2011 to 2014 I carried out research on the language policy of EITB and BBC ALBA. The research addresses a) in general, the language policy measures that have been implemented in order to face the digital challenge and b) in particular, the interactional or participative strategies employed to attract young people to the minority media and the media literacy strategies used with that goal in mind. It takes

\footnotetext{
Bòrd na Gàidhlig is an executive non-departmental public body, responsible to Ministers of the Scottish Parliament. Established under the Gaelic Language (Scotland) Act 2005, Bòrd na Gàidhlig is the principal public body in Scotland responsible for promoting Gaelic development and providing advice to Scottish Ministers on Gaelic issues. Among other tasks, the Bòrd must monitor and report to Scottish Ministers on the implementation of the European Charter for Regional or Minority Languages, dated 5 November 1992 in relation to the Gaelic language.

8 According to the 2011 census, in Scotland 87, 056 people have some knowledge of Gaelic and 57, 375 are able to speak the language.

9 This contribution has been researched and as yet it seems that there are no definitive results. Millingan et al. (2011) emphasise that BBC ALBA is able to make a tangible economic contribution to the Gaelic community, but question the limits of the media in terms of acquisition planning and usage planning.
} 
into account four research dimensions: 1) The creation of Internet platforms from 2002 to 2014 in EITB and MG/BBC ALBA and their language policy goals; 2) the inclusion of the young as a specific target audience to take into account in the media and language policy of EITB and MG/BBC ALBA; 3) the study of exploiting the interactive resources of the Internet in their Internet platforms for young people; and 4) the linguistic criteria used in that interaction with young people. In this paper, I will focus on the third dimension, in particular on the participative strategies undertaken by EITB and BBC-ALBA in their interaction with young people.

The research does not match a single theoretical framework. It involves a multidimensional approach to the study of language policy in digital media where I propose to study the implementation of language policies in minority media by integrating the findings of current studies of minority media (Cormack 2010, 2013; Jones \& Uribe-Jongbloed, 2013; Moring 2007, 2013, among others), language policy in minority languages and media (Androutsopoulos 2009, Kelly-Holmes 2001, Ricento 2007, among others) and sociolinguistic research on the specificities of new digital media communication (Androutsopoulos, 2010; Leppänen, 2009; Pietikäinen, 2008, among others) .

I used a methodological triangulation drawing data from: 1) Internal and public documents of BBC ALBA and EITB, such as annual plans and reports. In the content analysis of the documents I focused on the language policy goals of the Internet platforms for young people and the inclusion of the young target audience in the media strategy of those media entities; 2) Interviews with the management of those public media, and focus groups with the staff of the respective Internet departments. The interviewees are managers and professionals ${ }^{10}$ involved in creating and exploiting digital platforms in both BBC ALBA and EITB. Some of them are professionals in charge of young people's web products, such as the Scottish FilmG and the Basque Gaztea, which I will explain in following sections. The main goal of those interviews is to get information on the way those professionals understand the relationship between media strategy and minority language policy and to collect the measurements they implanted on the Internet platforms for young people in their media entities; and 3) Direct observations of the websites eitb.eus and bbcalba.com. In particular I have focused on two EITB and BBCALBA web products that take the young as their main target: the Scottish FilmG and the Basque Gaztea. I have analysed strategies that offer young people the chance to engage with the media by sharing, commenting and promoting content and also to create their own material or become involved in the design, production and distribution of content for media.

\footnotetext{
${ }^{10}$ I carried out face-to-face interviews of around 2 hours with the following Board members and professionals in BBC ALBA and EITB: Alan Esslemont, Head of Content at BBCALBA and in charge of Scottish FilmG (08/04/2013); Margaret Mary Murray, Main Director of BBCALBA (08/04/2013); Donald Campbell, Chief Director of BBCALBA (29-04-13); Maggie Cunningham, Head of MGALBA (18-04-13); Una MacDonald, Head of the Internet Team at BBCALBA (21-06-13); Patxi Arratibel, Strategy Director of EITB and Head of EITBnet (30-11-12); Edurne Ormazabal, Head of eitb. com (19-12-12); Iñako Gurrutxaga, Head of Entertainment at eitb.com and Hiru.com (20-12-12); Lontxo Sainz, Head of Networking at eitb.com (7-01-13); Iñigo Herce, Head of News at eitb.com (18-01-2013); Jon Lamarka, director of Gaztea (9-06-14); and Joseina Etxeberria, Radio broadcaster and in charge of DidaGaztea (19-06-14).
} 
Summarising very briefly some of the results of this study, I would contend that BBC ALBA and EITB are both responding to the potential of interactive media technologies and ensuring that Gaelic and Basque TV products can be consumed through any Internet platform (mobiles, tablets, and so on). It appears, then, that their institutional structures and priorities are getting closer to this participative Internet model, particularly in the use of social networking services (EITB, 2013; MG ALBA, 2014), and they are both improving the relationship with educational institutions in their MIL strategy ${ }^{11}$.

However, they are both still focused largely on linear broadcasting. Any Internet presence is mostly a product of 'shovelwaring' in Bardoel's (2007: 45) terms. Their websites are at present used to store linear materials, although in that sense I would highlight the fact that there has been remarkable progress. In the case of BBC ALBA, for instance, the on-demand content offered on the BBC IPlayer was initially quite limited (only 10 hours a week) up to the end of 2013; nowadays, however, BBC ALBA IPlayer offers almost all the BBC ALBA programmes on demand. Meanwhile, in June 2011 EITB started up Nahiera (EITB on-demand) whereby EITB offers on-demand digital material in Basque produced since the founding of EITB. Nowadays, according to the EITB annual report of 2013, eitb.eus offers 6,925 TV hours and 9,139 radio hours via this service ${ }^{12}$.

As for the audience target policy, according to the content analysis of the annual plans and reports and the interviews with the managers of the two media entities, neither of them includes a specific plan for young people, not even in the design of an Internet audience target policy, at least in the analysed period. In the case of BBC ALBA, in the interview I conducted with Maggie Cunningham, head of MG ALBA, in the spring of 2013 (18-04-2013), she acknowledged the lack of a plan for young people and emphasised the urgent need to design and implement such a plan at BBC ALBA. The plan has not been left waiting: according to the latest report published by MG ALBA in 2014 (MG ALBA 2014), in this last year a new project that aims to think about strategies to attract a younger audience has been launched: 'The organization's strategy for research was also developed and an ethnographic research project was commissioned to provide information on the media habits of young Gaelic speakers. The results of this research will be reviewed in 2014-15 and will inform future media strategies for young Gaelic speakers' (MG ALBA, 2014: 16).

However, even lacking a specific strategic plan for young people on the Internet, in the two media analysed there are indicators that come from radio and cinema/TV and that are being developed on the web. In this paper I will focus on two of EITB

\footnotetext{
${ }^{11}$ As for the MIL strategies, in the case of EITB I would highlight the collaboration involved in the UPV-EHU/EITB Multimedia Master's programme since 2009. In particular, the MultimediaLab media laboratory is an MIL project that, as of 2014, is in its fourth year as part of a collaborative effort between the University of the Basque Country (UPV-EHU) and EITB. The goal of this laboratory is to instruct Master's students in the theoretical and methodological foundations of multimedia communication through a practical immersion process, and also to give them the skills to work in groups with an international and multilingual profile. In 2012-13, MultimediaLab worked together with the Korrika 18 as part of a transmedia project with Tabakalera and AEK called MultimediaLab Korrika. The practical week culminated in the creation of several digital products to be published by various EITB media.

${ }^{12}$ The report does not include data on how many are in Basque and how many in Spanish.
} 
and BBC ALBA's web products that take the young as their main target: the Scottish Film $G$ and the Basque Gaztea are the main media products aimed at young people in those minority media and the ones I have analyzed from a participative perspective. Our analysis focused on participative initiatives found on the websites and specific sections aimed at encouraging participation. I took into account several participation strategies through cross-media activities. Following the interaction strategies proposed by Bardoel (2007), I have analyzed strategies that offer young people the chance to engage with the media by sharing, commenting, promoting or criticizing content and also the option to create their own material or become involved in the design, production or distribution of content for media.

Particularly important in this respect are participative tools that encourage debate -including forums, chat services, citizens' blogs and comments on content and special sections with the option of expressing their views. Our analysis also includes tools for sharing content through social media such as Twitter and Facebook, where users exchange and distribute content. Finally I have observed the existence of applications for sending videos, pictures, texts and audio to the media's production departments and elements for the evaluation of content, such as polls and ratings. Let us see some results of that analysis.

\subsection{Film G a MIL project of $B B C A L B A$}

FilmG is a Gaelic short film project run by BBCALBA that is now entering its sixth year ${ }^{13}$. FilmG is a participatory policy experiment based in on the user-generated content though the inclusion of Media and Information Literacy within the public media. The project has two distinctive interlinked elements: the Competition and the Training Programme and a final awards ceremony. The FilmG competition is open to anyone aged 12 years or older. There are two main competitions, one for those aged between 12 and 17 and another one for adults. The film must be between 3 and 5 minutes in length and always in Scottish Gaelic. In this project media and schools work together. In the schools, media professionals provide support through lessons, books and workshops to help the student groups through the whole process of making a film. Also once the script is complete, the media professionals of the FilmG team meet with them to do a day of filming and a day of editing. In the Training Programme, BBCALBA offers language assistance through TàlantG ${ }^{14}$ : to adults who would like to gain knowledge of film-making and to schools through their filmmaking workshops.

Film $G$ mainly uses the web to distribute its final products and also to disseminate information about the competition. In the 2012-13 edition, for the first time, FilmG used tools for sharing content through links to social media such as Facebook and Twitter, in which users exchange and distribute content. FilmG uses elements such as surveys of the Internet audience designed to evaluate the film in question and these are taken into account when it comes to the competition prizes for the People's Choice Award. In that edition they did not use the web in the training process. In the latest 2013-14 edition, however, there was a significant increase in the use of all

\footnotetext{
${ }^{13}$ The full project is managed by Cànan, with support from MGALBA staff.

${ }^{14} \mathrm{http}$ ://filmg.co.uk/en/training-and-support/talantgI
} 
those participative elements. They also included web training: they offer workshops to schools or youth groups that would like to make a film. Furthermore, FilmG has created a variety of resources, such as video tutorials, for young filmmakers who would like to make a Gaelic-language film.

\subsection{Gaztea a participative radio-website of EITB}

It was firstly a radio station ${ }^{15}$ created as Euskadi Gaztea in the 90's. Now Gaztea is also a radio-website with a clear cross-media approach. All the radio programs on Gaztea have web development (Dida, Akabo Bakea). We can listen to and watch them on the website in several formats (audios, videos, pictures...). It has a commercial character and offers content related to young people's music interests: new albums or music releases, concerts as well as interviews, videos and tickets for the main music festivals in the Basque Country (such as Bilbao BBK Live and Azkena Rock).

Gaztea includes several participative tools in its website: a) elements that encourage debate, including forums and comments on new albums and festivals and special sections with the option of expressing young people's views; b) tools for sharing content through social media such as Tuenti, Twitter and Facebook, where users exchange and distribute content. c) They have applications for sending videos, pictures and texts. In fact in recent years they have promoted several participative projects for young people to share content on the website: Maketa Lehiaketa, a demo competition for new music groups that have not yet signed with record companies; Bideoklip lehiaketa and Parody competitions concerning music videos that any group of friends can enter. Destination EH is their latest project, in which young people are encouraged to make a promotional video of the Basque Country. It is based on the US project MyDestination's Biggest, Baddest Bucket List.

Gaztea also takes part in events whereby Basque young people can become involved, particularly those related to the Basque-speaking Community, such as the case of the Korrika ${ }^{16}$. This year Gaztea worked on a specific project called Korrika MultimediaLab in the Korrika 18 as part of a transmedia project with Tabakalera, the University of the Basque Country and AEK (Arana et al. 2013). The results in terms of the audiences in the Gaztea Twitter account were excellent. The Korrika project was the main reason for this (EITB, 2013).

\subsection{Successful measures in statistical terms}

Gaztea is nowadays one of the main drivers of the Internet audience of the whole EITB group (OJDInteractiva, 2013) and, together with Goenkale, the most successful

\footnotetext{
${ }^{15}$ According to the study of media preferences by the Basque Government's Basque Youth Observatory in 2012, Gaztea radio station is the second most listened to among young people in the Basque Country (32\%), very close to its direct competitor, the most popular Spanish radio station for young people Los 40 principales (39\%) (Basque Government 2012: 34). At present Gaztea has 134,000 listeners and it is the top music radio broadcaster in the Gipuzkoa and Araba provinces of the Basque Country (EITB, 2013: 22).

${ }^{16}$ The Korrika, or Running, is an exhibition race held bi-annually in the Basque Country in order to celebrate and support the Basque Language. The race is organized by the AEK (Basque acronym for the Coordinator of the Promotion of and Literacy in the Basque Language).
} 
EITB sub-website in Basque (EITB, 2012). According to Jon Lamarka, director of Gaztea, in an interview I conducted with him in June 2014, there is a correlation between the use of those participation strategies and an increase in the number of visits to the Gaztea website, and this has also had a major effect in increasing the movement in its social networks. In March 2013, with the launch of Maketa Lehiaketa, for instance, Gaztea received almost twice as many visits on the web (86,193 visits) than in the previous and following months ${ }^{17}$.

Film $G$ is also becoming more and more successful among young people in the Scottish Gaelic community. FilmG receives an agreed number of film submissions from target groups annually. The data published by MG ALBA in its last annual report (MG ALBA 2014) reveals that every year there is a substantial increase in the number of entries into the FilmG competition (23\% more in the last year) and there was a $375 \%$ increase in visits to the FilmG website in 2013. The growth in traffic last year BBC ALBA's Twitter (167\%) and Facebook (101\%) accounts seems to be largely related to the success of FilmG on social networks (MG ALBA 2014: 18).

The success of those two media products is probably related to many factors that need deeper research. In the case of Gaztea, its commitment to commercial modern music is probably a relevant factor ${ }^{18}$. However, the fact that they encourage young people to create, enjoy and become active within minority media is very much a factor to take into account. They follow the interaction strategies that, according to Bardoel (2007: 45), are needed to improve the relationship between broadcasters and their young public. They are giving the young the possibility of engaging with the media and also the option of elaborating their own material or getting involved in the design, production or distribution of content for media. They are trying to develop and grow an online community of people actively interested minority media content.

\section{Conclusions}

Youth behaviour is an indicator of future developments and, because of that, an important indicator in media and language policy. The effectiveness of media Internet policies will depend on their ability to attract those young users and encourage them to interact with the media by sharing their experiences and participating in the media as content producers. Yet in this new media model minority media policymakers have to face the extra challenge of attracting young people to active use in the minority language. It is particularly difficult in a media linguistic context characterised by heteroglossic interactions in which major languages like English and Spanish are so linked to media consumption.

The new means of Internet consumption has led in recent years to a reflection on the need for a new approach to the public service of the media. The described challenging context minority media face nowadays show us that, together with that reflection, there is also a need to rethink a new language policy for public minority media. Many could think that the only possible strategy is not to implement

\footnotetext{
${ }^{17}$ According to the statistical data used by Gaztea every month, there are around 50,000 visits to the web: for example, 54,442 visits in February and 49,732 visits in April 2013.

${ }^{18}$ According to the Basque Government's Youth Observatory study on the Basque youth's media consumption, $83 \%$ of Basque young people listened to the radio to consume modern music.
} 
a particular language policy for revitalisation, in other words, that nothing can in effect be done. Others, however, see this as an opportunity to build a media context in which young people can contribute to creating both a community and also media content in minority languages (Cormack, 2013; Jones\& Uribe-Jongbloed, 2013; Moring, 2013). This second view requires attuning the goals and strategies of minority media and language policymakers in order to make new media spaces available in which the young engage in media activities that are meaningful for them. Such a language policy must be integrated into the general policy of minority media. Questions raised regarding the strategy of content, the strategy of distributing content and the audience target strategy of minority media must be major issues on the research agenda of any language policy.

But it also asks for a change in the way we understand the role of media service for revitalising minority languages. First of all, it must be taken into account the fact that the mere existence of media services in the minority languages does not ensure that young people will choose them. Jon Lamarka and Alan Esslemont, the respective heads of Gaztea and FilmG, know that from experience, and they emphasise in the interviews that their main goal is not just to offer a media service in the minority language; instead, first and foremost they want to run a really good and entertaining media service for young people, which just happens to broadcast in Gaelic and Basque.

Moreover, that new conception of language policy has to bear in mind that in the logic of the young consumers and prosumers the interaction with media products and the creation of their own media products is a priority. In that new context, a topdown language planning based on functional completeness and standardisation, is not enough, and probably not even appropriate. As Pietikäinen (2008) points out, the logic of the minority-language speaker as a producer and a consumer (as a prosumer) is very far from what she calls the 'gifting' era of media policy where the main goal was to ensure that minority languages were present in media, and even far from the 'service era' of functional completeness. In the 'performance era' of today, young people interact with media and create their own media products. They want a media that help them to promote and expand them as much as they can.

As for the corpus planning, it must be taken into account that in the new media context, more than ever, standard varieties constitute just part of a diversified and fragmented media linguistic ecology. New media language policy must address the most obvious sociolinguistic consequence of the decentring of the media, that is, the increase in inter and intra linguistic heterogeneity among young people's use (Androutsopoulos, 2009; Elordui, 2015, 2016). Such a planning should relinquish the concept of language policy in terms of the traditional media based on a top-down view related to procedures for standardising the language in order to embrace a new language policy understood as a stimulus for language usage dynamism in the minority media.

In successful participative proposals, such as the cases of FilmG and Gaztea that I have analysed here, we can find interesting guidelines to follow in that new policy. Film $G$ and Gaztea both use participative strategies that are probably one of the keys to their success. They both try to encourage minority language speakers to create, enjoy and become active within minority media, to be part of them. They also try to encourage and develop new skills within minority-language communities in the 
minority language and to generate new content in the minority language for online consumption. Finally, they both try to develop and cultivate an online community of people actively interested in creating, sharing and consuming minority media content.

\section{References}

ANDROUTSOPOULOS, Jannis (2009). Policing practices in heteroglossic mediascapes: a commentary on interfaces. Language Policy 2009 (8), pp. 285-290.

ANDROUTSOPOULOS, Jannis (2010). Localizing the Global on the Participatory Web. In N. Coupland (ed.), The Handbook of Language and Globalization (203231). Oxford: Wiley-Blackwell.

ARANA, Edorta; NARBAIZA, Bea \& MIMENZA, Libe (2013). Korrika: una visión transmedia, in M. Ledo \& M. I. Vassallo de Lopes (eds.). Libro de Actas. XIII Congreso Internacional Ibercom. Santiago de Compostela: IBERCOM, AssIBERCOM, AGACO, pp. 2533-2544.

BARDOEL, Jo (2007). Public service broadcasting in a multimedia environment. In N. Carpentier et al. (eds.) Media technologies and democracy in an enlarged Europe. The intellectual work of the 2007 European media and communicational doctoral summer school (41-54). Tartu: Tartu University Press.

BARDOEL, Jo \& d'Haenes L. (2008) Reinventing public media broadcasting in Europe. Prospects, promises and problems. Media, Culture and Society 30 (1), pp. 337-355.

BASQUE GOVERNMENT (2012a). Gazteen argazkiak 15. Hedabideak. Report of the Basque Observatory of Youth. Vitoria-Gasteiz: Spain. Available also in Spanish at: http://www.euskadi.net/contenidos/informe_estudio/retratos_de_juventud_15/eu_retjuv15/adjuntos/11retratos15_eu.pd

BASQUE GOVERNMENT (2012b). Euskara sustatzeko ekintza plana. Vice Ministry for Language Policy. Vitoria-Gasteiz: Spain. Available also in Spanish at: http://www.euskara.euskadi.net/r59738/es/contenidos/informacion/argitalpenak/ es_6092/adjuntos/Plan\%20ESEP_cast.pdf

BASQUE GOVERNMENT (2013). Firth Sociolinguistic Survey. Vice Ministry for Language Policy. Vitoria-Gasteiz: Spain. Available at http://www.euskara. euskadi.net/r59-738/en/contenidos/informacion/sociolinguistic_research2011/ en_2011/2011.html

BBC (2013). BBC Media Literacy Strategy. Available at http://www.bbc.co.uk/learning/overview/about/assets/bbc_media_literacy_strategy_may2013.pdf

BORD NA GAIDHLING (2012). National Gaelic Language Plan 2012-2017. Growth and Improvement. Available at: http://www.gaidhlig.org.uk/Downloads/ National\%20Gaelic\%20Langauge\%20Plan\%202012\%20-\%202017.pdf

BROWNE, Donald R. \& URIBE-JONGBLOED, Enrique (2013). Introduction: Ethnic/Linguistic Minority Media -What their History Reveals, How Scholars have 
studied them and What we might ask next. In Jones Elin Haf Gruffydd \& UribeJongbloed, Enrique (eds.), Social Media and Minority Languages: Convergence and the Creative Industries (1-28). Bristol: Multilingual Matters.

CLARK, Jessica \& AUFDERHEIDE, Pat (2009). Public Media 2.0: Dynamic, Engaged Publics. Future of public media.net . Available at http://www. centerforsocialmedia.org/future-public-media/documents/white-papers/ public-media-20-dynamic-engaged-publics

CORMACK, Mike (2010). Gaelic in the new digital landscape. In G. Unro \& I. Mac an Tàilleir (eds.) Gaelic Communities Today (127-137). Edinburgh: Dunedin Academic.

CORMACK, Mike (2013). Concluding Remarks: Towards an understanding of media impact on minority language use. In Elin Haf Gruffydd Jones and Enrique Uribe-Jongbloed (eds.). Social Media and Minority Languages: Convergence and the Creative Industries (255-265). Bristol: Multilingual Matters.

EITB (2013). Txostena 2013 Balance. Available at www.eitb.eus

ELORDUI, Agurtzane (2015). Diseinu linguistikoa eta transmedia-engaiatzea: Gaztea, audientziari begira prosumitzaileen aroan. In Agurtzane Elordui and Edorta Arana (2015) Transmedia Komunikazio estrategiak. Gaurkotasun-edukiak diseinatzeko eta hedatzeko bide berriak (135-154). Bilbo: Udako Euskal Unibertsitatea.

ELORDUI, Agurtzane (2016). Elebakartasunetik heteroglosiara: Gaztea Irratia, bernakulizazioa gazte-komunikabideen diseinu sozioestilistikoan. Uztaro 97, pp. 31-52.

JAKUBOWICK, Karol (2006a). If not us, then who?" Public service broadcasting and culture in the 21st century. In C. Nissen (ed.) Making a difference: Public Service Broadcasting in the European Media Landscape. Eastleigh: John Libbey Publishing.

JAKUBOWICK, Karol (2006b). Comments on the report on 'Access of national minorities to the media: new challenges' Council of Europe. Available at http://www.coe.int/t/dghl/monitoring/minorities/6_Resources/ PDF_DH-MIN_KJakubowicz_CommentsAccessNatMinMedia_en.pdf

JAKUBOWICK, Karol (2007). Public service broadcasting: a new beginning, or the beginning of the end? Knowledge Politics. Available at www.coe.int/t/dghl/ standardsetting/.../PSB_Anewbeginning_KJ_en.pdf $\square$

JAKUBOWICK, Karol (2008). Participation and Partnership: A Copernican Revolution to engineer public service media for the $21^{\text {st }}$ century. RIP@ Keynote Presentation.

JENKINS, Henry (2006). Convergence Culture: Where Old and New Media Collide. New York: New York University Press.

JENKINS, Henry; FORD, Sam; GREEN, Joshua (2013). Spreadable Media: Creating Value and Meaning in a Networked Culture. New York: New York University Press.

JONES, Elin Haf Gruffydd \& URIBE-JONGBLOED Enrique (eds.) (2013). Social Media and Minority Languages: Convergence and the Creative Industries. Bristol: Multilingual Matters.

KELLY-HOLMES, Helen (ed.) (2001). Minority language broadcasting: Breton and Irish. Clevedon: Multilingual Matters. 
LEPPÄNEN, Sirpa; PITKÄNEN-HUHTA, Anne; PIIRAINEN-MARSH, Arja; NIKULA, Tarja; PEURONEN, Saija (2009). Young People's Translocal New Media Uses: a Multiperspective Analysis of Language Choice and Heteroglossia. Journal of Computer-Mediated Communication 14, pp. 1080-1107.

LIVINGSTONE, Sonia (2009). Children and the Internet. Cambridge: Polity Press.

LIVINGSTONE, Sonia \& Das, Ranjana (2010). POLIS media and family report. POLIS, London School of Economics and Political Science, London, UK. Available at: http://eprints.lse.ac.uk/30156/

LIVINGSTONE, Sonia (2013). The end of audiences? Theoretical echoes of repeption amid the uncertainties of use. In Hartley, Jonh, Burgess, Jean and Bruns, Axel (eds.) A companion to new media Dynamics (104-121). Oxford: Wiley-Blackwell.

LIVINGSTONE, Sonia \& Wang, Yinhan (2011). Media policy brief 2. Media literacy and the Communications Act. What has been achieved and what should be done? London: London School of Economics Media Policy Project. Available at http://www2.lse.ac.uk/media@1se/pdf/MPP/LSEMPPBrief2.pdf

MCGONAGLE, Tarlach (2011). Minority rights, Freedom of Expression and of the Media: Dynamics and Dilemmas. School of Human Rights Series 44. Cambridge: Intersentia.

MGALBA (2014). MGALBA Annual Report Statement of Account 2013-2014. Available at: http://www.mgalba.com/downloads/reports/annual-report-13-14. pdf?lang

MILLINGAN, Lindsay; CHALMERS, Douglas; DANSON, Mike; LANG, Alison (2011). BBC ALBA's contributions to Gaelic language planning efforts for reserving language shift. Current Issues in Language Planning, 12 (3) pp. 349-361.

MORING, Tom (2006). Access of National Minorities to the media: new challenges. Report for the $4^{\text {th }}$ meeting of the Committee of Experts on Issues Relating to the Protection of National Minorities, 19-20 October 2006, Strasbourg, France.

MORING, Tom (2007). Functional Completeness on Minority Language Media. In Mike Cormack \& Niamh Hourigan (eds.), Minority Language Media: Concepts, Critiques, and Case Studies. (17-33). Clevedon: Multilingual Matters.

MORING, Tom (2013). Media Markets and Minority Languages in the Digital Age. Journal on Ethnopolitics and Minortity Issues in Europe. 12 (4), pp. 34-53.

MORING, Tom \& Dunbar, Robert (2008). The European Charter for Regional or Minority Languages and the Media. Strasbourg: Council of Europe Publishing.

OFCOM (2007). A new approach to public service content in the digital media. The potential role of the Public Service Publisher. Ofcom Office of Communication. Available at http://stakeholders.ofcom.org.uk/consultations/pspnewapproach/

OFCOM (2014a). Children and parents: Media use and attitudes in the nations . Ofcom Office of Communication. Available at http://stakeholders.ofcom.org.uk/ market-data-research/market-research/

OFCOM(2014b).Communications MarketReport.Availableathttp://stakeholders.ofcom.org.uk/market-data-research/market-data/communications-market-reports/ cmr14/uk/

OJDINTERACTIVA (2013). Auditoria de medición de audiencias. Información y control de publicaciones de EITB, Available at: http://www.ojdinteractiva.es/ medios-digitales 
PIETIKÄINEN, Sari (2008). To breathe two airs: empowering indigenous Sámi media. In P. Wilson and M. Steward (eds.), Global indigenous media: cultures, practices and politics (197-213). Durham, NC: Duke University Press.

PIETIKÄINEN, Sari and KELLY-HOLMES, Helen (2011). Gifting, service, and performance: three eras in minority-language media policy and practice. International Journal of Applied Linguistics, 12(1), pp. 51-70.

RICENTO, Thomas (ed.) (2007). An introduction to Language Policy. Theory and Method. Malden: Blackwell Publishing.

SCOTT, Martin (2009). Guidelines for broadcasters on Promoting User-generated Content and Media and Information Literacy. Commonwealth Broadcasting Association \& UNESCO. Available at www.unesdoc.unesco.org/ images/0018/001871/187160e.pdf

STÙBHART, Mòrag (2008). NPLD Youth Project 08: Priorities for promoting language diversity among young people.). NPLD Youth report: Scottish Gaelic. NPLD. Available at http://www.npld.eu/

UNESCO (2011a). Public Service Broadcasting and Language Development: A Summary Report on the Situation in Five Countries. Report for the expert group meeting "Towards UNESCO guidelines on Language Policies: a Tool for Language Assessment and Planning. Available at www.unescobkk.org/.../public_service_broadcasting.pdf

UNESCO (2011b). UNESCO's Language Vitality and Endangerment Methodological Guideline: Review of Application and Feedback since 2003. Available at http://www.unesco.org/new/fileadmin/MULTIMEDIA/HQ/CI/CI/pdf/unesco_ language_vitaly_and_endangerment_methodological_guideline.pdf 